Sains Malaysiana 48(1)(2019): 137-144

http://dx.doi.org/10.17576/jsm-2019-4801-16

\title{
Long Term Effect of Cryopreservation on Primary Human Skin Cells
}

(Kesan Jangka Panjang Pengawetan Krio pada Sel Kulit Primer Manusia)

\author{
ISHAK, M.F., MANiRA, M., NG, M.H., Khairul, B., GARGY, L., AMINUdDin, B.S. \& RusZYMAH, B.H.I.*
}

\begin{abstract}
Cryopreservation is essential for tissue engineering and regenerative medicine. This study was carried out to assess the effect of cryopreservation on skin cells and evaluate the performance of cells after 12 months of cryopreservation. Redundant skin tissue samples were obtained from surgery with consent from patients. The tissue was cleaned, processed and cultured until passage 3. Upon confluency, cells were trypsinised and total cell yield and viability were determined before and after being cryopreserved. Sterility and immunocytochemistry analysis for collagen type I (Col-1) and cytokeratin 14 (CK14) antibodies were also performed on cells cryopreserved for one, three, six and twelve months. There is no significant difference in growth rates for cryopreserved cells for 1 to 12 months, except for fibroblasts at 6 months. Cell viability for both keratinocytes and fibroblasts decreased with time (65\% $3.5 \%-89 \% \pm 4.5 \%)$. Sterility testing showed no contamination after 12 months of cryopreservation. Immunocytochemistry analysis showed positive expression for CK14 (keratinocytes) and Col -1 (fibroblasts) after 12 months of cryopreservation. Morphologically, keratinocytes and fibroblasts were able to retain its phenotype. The loss in viability is consistent in all samples and possibly due to thermal-cycling effect.Immunocytochemistry and consistent cell growth analysis showed that keratinocytes and fibroblasts were able to retain their characteristics in cryopreservation condition. These preliminary findings show that primary skin cells can be stored via cryopreservation and still retain their characteristics. However, further investigations using longer periods of cryopreservation (24 months, 48 months) should be conducted.
\end{abstract}

Keywords: Cell proliferation; cryopreservation; human skin cells; gene expression

ABSTRAK

Pengawetan krio adalah penting bagi bidang kejuruteraan tisu dan penjanaan semula perubatan. Kajian ini dijalankan untuk menilai kesan pengawetan krio pada sel kulit dan prestasi sel selepas pengawetan krio selama 12 bulan. Sampel tisu kulit berlebihan daripada pembedahan diambil dengan kebenaran pesakit. Tisu dibersihkan, diproses dan dikultur sehingga subkultur 3. Selepas mencapai kepadatan sesuai, sel dituai dan jumlah keseluruhan sel berserta keviabelan sel ditentukan sebelum dan selepas pengawetan krio. Ujian kesterilan dan imunositokimia menggunakan antibodi kolagen jenis I (Col-1) dan sitokeratin-14 (CK14) dijalankan terhadap sel bagi bulan pertama, ketiga, keenam dan kedua belas. Tidak terdapat perbezaan signifikan bagi kadar pertumbuhan sel yang telah diawet bagi bulan pertama dan kedua belas, kecuali bagi sel fibroblas pada bulan keenam. Keviabelan sel bagi keratinosit dan fibroblas menurun mengikut peningkatan masa $(65 \% \pm 3.5 \%-89 \% \pm 4.5 \%)$. Ujian kesterilan menunjukkan tiada sebarang pelumusan selepas dua belas bulan pengawetan krio. Secara morfologi, keratinosit dan fibroblas mampu mengekalkan fenotipnya. Pengurangan keviabelan adalah konsisten bagi semua sampel dan ini mungkin berlaku akibat daripada kesan kitaran terma. Analisis imunositokimia dan pertumbuhan sel yang tekal menunjukkan bahawa keratinosit dan fibroblas berupaya untuk mengekalkan cirinya setelah pengawetan krio. Keputusan awal ini menunjukkan sel kulit primer boleh disimpan melalui proses pengawetan krio dan cirinya dikekalkan. Namun, kajian lanjutan menggunakan tempoh pengawetan krio yang lebih lama (24 bulan, 48 bulan) perlu dijalankan.

Kata kunci: Pengawetan krio; pengekspresan gen; sel kulit manusia; sel pembiakan

\section{INTRODUCTION}

Regenerative medicine, as its name implies, involves regeneration of organ or tissue, an approach towards treating different degenerative diseases. One of the earliest initiatives of regenerative medicine has been skin regeneration, due to the simplicity of its structure and accessibility. Being the outer layer of the body, skin is the largest organ in human, which also functions as the first line of defence. Hence, huge skin loss, resulting from trauma, burns or diabetic ulceration, can be fatal and requires special attention and sometimes extensive measures (Kalyanaraman \& Boyce 2009). History implies, that culturing epidermal keratinocytes has started way back in 1970's, pioneered by Rheinwald and Green (1975). Since then, a few different methods were developed to explore regeneration of the single and bilayer skin equivalents. Manipulation of skin cells, which consists mostly of keratinocytes and fibroblasts require several standard 
steps: Cell isolation from a skin biopsy, cell isolation through digestion, cell proliferation in monolayer culture, construction of bilayered skin in the form of fibrinfibroblast and fibrin-keratinocyte skin equivalent, and finally implantation on the damaged area (Mazlyzam et al. 2007).

At the same time, storage methods of the cells and engineered tissues also have received much attention. One of the most widely used cell storage method is cryopreservation. Cryopreservation is a process where living cells or tissues are stored at $-196^{\circ} \mathrm{C}$ in liquid nitrogen. At this temperature, biological activities including biochemical reactions causing cell death, are effectively halted. In the absence of cryoprotectants, preserved cells are likely to be damaged due to freezethawing process. Synth-a-Freeze and dimethylsulfoxide (DMSO) $+10 \%$ Feotal Bovine Serum (FBS) are frequently used as cryoprotectants for keratinocytes and fibroblasts, respectively. Synth-a-Freeze is a defined, liquid cryopreservation medium that contains $10 \%$ (DMSO) without any growth factors, hormones, antimycotics, antibiotics, serum or proteins while 4-(2-hydroxyethyl)1-piperazineethanesulfonic acid (HEPES) and sodium bicarbonate function as buffers. Synth-a-Freeze was manufactured for freezing and storing mammalian cells which include human keratinocytes and stem cells (mesenchymal, neural and embryonic). DMSO has also been widely used for cryopreserving different cells and tissues. Even though the current cryopreservation methods have proven to be clinically effective, its optimal level is still in question (Hunt 2011).

A previous study demonstrated that the skin substitute MyDerm $^{\mathrm{TM}}$ can be kept in pure F12: DMEM medium at $4^{\circ} \mathrm{C}$ for up to 3 days $(72 \mathrm{~h})$, in which good cell viability and population doubling time were maintained (Seet et al. 2012). This has been possible due to the ability to cultureexpand skin cells in vitro and thus allow researchers to propagate and manipulate them for various purposes (Adha et al. 2008; Law et al. 2016; Manira et al. 2014; Mazlyzam et al. 2008, 2007, 2004; Muhd Fakhruddin et al. 2004; Norhayati et al. 2004; Ruszymah et al. 2011). There has been extensive initiatives for cryopreservation of different human-derived cells such as haematopoetic stem cells (Hunt et al. 2006; Liu et al. 2008; Rubinstein et al. 1995), mesenchymal stem cells (Woods et al. 2009; Zhou et al. 2004), embryonic stem cells (Zhou et al. 2004) and neural stem cells (Ortiz-Lopez et al. 2017). Several cryopreservation studies on epidermal cells involve the process of culturing and freezing (Pasch et al. 1999; Teepe et al. 1990). However, assessments of the condition of the cells following long-term cryopreservation has not been widely conducted (Roseeuw et al. 1991; Schiozer et al. 2013). Under certain circumstances, the collection of cells in advance and cryopreserving the cells is a good alternative, where the cells may be used at a later time for research purposes and possibly for further clinical applications. Currently, it is difficult to obtain human primary cells in the market as the cost is high.
Cryopreservation will ensure continuous cell availability should contamination or problems during the culturing period or a shortage of cell supply occur. The best time to cryopreserve the cells is when they are at optimal growth or when the cells are reaching confluency. The risk of progressive loss of viability over time, associated with freezing and thawing procedures is minimised if the storage conditions are adequate (Rowley et al. 1994). The use of cryopreservation agents on stem cells has been shown to cause some adverse effects such as adverse transfusion reactions; and cellular damage during the process of cryopreservation (Brockbank et al. 2011; Gurtovenko \& Anwar 2007). Cells or samples that are cultured or manipulated have also been shown to have a higher rate of bacterial contamination as compared to fresh samples or product (Frey et al. 2006). Thus, this study was performed to assess the effect of cryopreservation on primary human dermal fibroblasts and keratinocytes and to evaluate the performance of these cells after 12 months of cryopreservation.

\section{MATERIALS AND METHODS}

\section{PREPARATION AND CULTURE OF CELLS}

Skin samples were obtained from surgery with consent from four healthy patients, aged between 6 and 60 years. The redundant skin $\left(1 \times 3 \mathrm{~cm}^{2}\right)$ were cleaned thoroughly, swabbed using $70 \%$ alcohol and rinsed with Dulbecco's phosphate buffered saline (DPBS) (Gibco/BRL, USA) before being cut into smaller pieces. The tissue samples were then digested in $0.6 \%$ Collagenase Type I for $5-6 \mathrm{~h}$ in a $37^{\circ} \mathrm{C}$ shaker incubator. This was followed by digestion using $0.05 \%$ Trypsin- EDTA for 8-10 min to dissociate the cells. The digested cell were then resuspended in co-culture medium [Epilife medium with Human keratinocytes growth supplement (HKGS) (Gibco/BRL, USA) + F12: DMEM (Sigma-Aldrich) with 10\% FBS (Gibco/BRL, USA)] and cultured in three wells of a six-well plate at $37^{\circ} \mathrm{C}$ in $5 \%$ $\mathrm{CO}_{2}$ with replacement of medium every 2-3 days. After reaching $70-80 \%$ confluency, the fibroblasts were removed from the co-culture by using Tryple Select (Gibco/BRL, USA) and sub-cultured into T75 flask using FD+10\% FBS until passage $3(\mathrm{P} 3)$. The remaining keratinocytes were then cultured using Epilife medium in a six-well plate throughout the study. When the keratinocytes reached 70$80 \%$ confluency, they were sub-cultured until a maximum of passage $3(\mathrm{P} 3)$ with medium replaced every 2-3 days.

\section{MEASUREMENT OF CELL PROLIFERATION}

The cell suspensions were diluted in Trypan Blue dye (Sigma, USA) and the viable and non-viable cells were determined by using a haemacytometer (Weber, UK). Total cell count and viability were performed for each passage before and after cryopreservation for one, three, six and twelve months. The growth rate for both keratinocytes and fibroblasts were calculated based on Chowdhury et 
al. (2012) using the following equation (Chowdhury et al. 2012).

$$
\begin{aligned}
\text { Growth rate }\left(\mathrm{h}^{-1}\right)= & \operatorname{Ln}(\text { Final } / \text { Initial cell } \\
& \text { concentration }) / \text { time }
\end{aligned}
$$

\section{CELL CRYOPRESERVATION}

Keratinocytes and fibroblasts were trypsinised upon reaching 70-80\% confluency. Determination of total cell number, viability and sterility were performed prior to cell cryopreservation. The appropriate cryo-medium (synth-a-freeze for keratinocytes and FBS $+10 \%$ DMSO for fibroblasts) were added to the cell pellet to resuspend the cells. The concentration of the cell suspension in one cryotube was maintained at $\sim 1 \times 10^{6}-1.5 \times 10^{6}$ cells $/ \mathrm{mL}$. The cryotube was placed into CoolCell ${ }^{\circledR}$ freezing container (Corning, USA) and equilibrated at room temperature and then transferred into a $-80^{\circ} \mathrm{C}$ freezer for $8-12 \mathrm{~h}$. The frozen cells were later transferred into the vapour phase of the liquid nitrogen storage system for a maximum of one year for further analysis.

\section{THAWING AND RE-CULTURE OF CRYOPRESERVED CELLS}

The cryovials containing the cells were removed from the cryopreservation system (liquid nitrogen tank) and thawed at $37^{\circ} \mathrm{C}$ in a water bath with gentle shaking until it is thawed completely. The cells were then immediately transferred into a pre-warmed medium and seeded into six-well plates or T75 flasks. The medium was replaced with a fresh medium to remove the cryoprotectant after the cells attached to the culture surface.

\section{STERILITY TESTING}

Sterility testing involved the use of cell suspensions before cryopreservation and spent medium after re-culture of the cryopreserved cells. The cell suspension or spent medium were transferred onto an agar plate via droplet or streaking.
The agar plate was incubated at $37 \pm 2^{\circ} \mathrm{C}$ for at least 3 days before observation.

\section{IMMUNOCYTOCHEMISTRY STAINING}

Re-culture of fibroblasts and keratinocytes for cryopreservation at one, three, six and twelve months were fixed using 4\% paraformaldehyde (Sigma- Aldrich) for $15 \mathrm{~min}$. The samples were later permeabilised with $0.1 \%$ Triton X-100 solution (Sigma-Aldrich) for $20 \mathrm{~min}$ and blocked with $10 \%$ goat serum (Sigma-Aldrich) for 1 $\mathrm{h}$ at $37^{\circ} \mathrm{C}$. The cells were later incubated using primary antibodies. Fibroblasts were conjugated using mouse antiCollagen type I monoclonal antibody (Abcam) whereas keratinocytes were conjugated using mouse anti-cytokeratin 14 monoclonal antibody (Millipore), respectively. After $24 \mathrm{~h}$, cells were then incubated with Alexa Fluor 594 goat anti-mouse IgG (Invitrogen) for 2 hours at $37^{\circ} \mathrm{C}$ and counterstained with 4',6-diamidino-2-phenylindole (DAPI) (Dako) for $20 \mathrm{~min}$. The immunocytochemistry staining results were analysed using a Nikon fluorescence microscope (Nikon, Tokyo).

\section{STATISTICAL ANALYSIS}

The quantitative results were analysed with one-way analysis of variance (ANOVA) and shown as the mean \pm standard deviation (SD). The differences were considered as significant if the $p$-value is less than 0.05 .

\section{RESULTS AND DISCUSSION}

Viability, Growth Profile Analysis and Cell Morphology The viability of the cryopreserved cells gives an early indication whether cells were able to withstand the storage condition as well as the general overview of the effectiveness of the cryopreservation agents used in this particular study. The study showed that cell viability decreased with time for both keratinocytes and fibroblasts $(65 \% \pm 3.5 \%-89 \% \pm$ $4.5 \%$ ) (Figure 1), with significant differences between a.

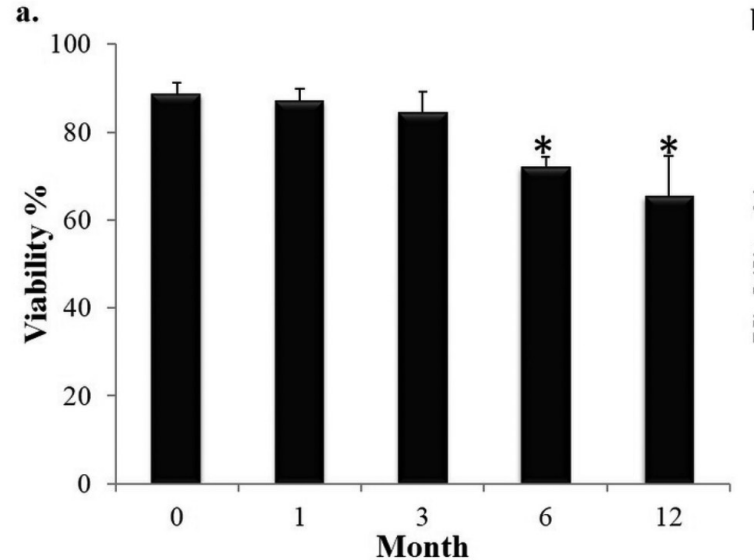

b.

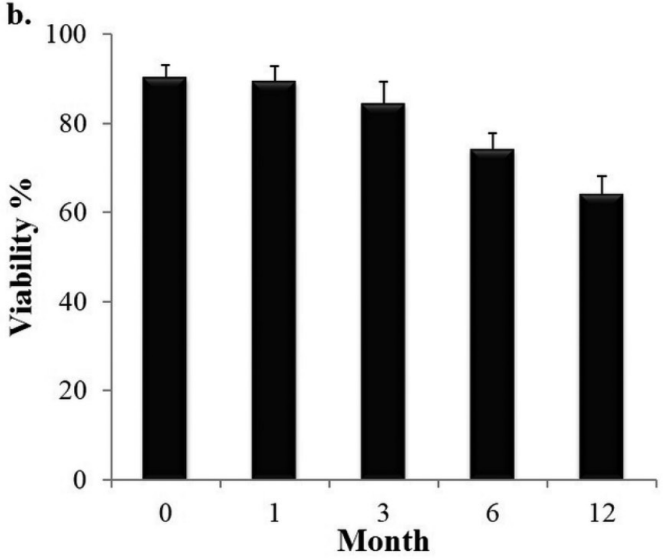

FIGURE 1. Percentage of viability of a) fibroblasts and b) keratinocytes. Both cells showed viability of more than $60 \%$ after 12 months of cryopreservation. *represents significantly lower compared to 0 month. $p<0.05$ 
six months and twelve months as compared to the first month. The growth rate of the re-cultured keratinocytes and fibroblasts after being cryopreserved for 1-12 months were measured and the results showed no significant difference between all groups compared to the non-cryopreserved cells ( 0 month) (Figure 2$)$. This indicates that the cells still proliferated actively even after being cryopreserved for twelve months. However, there is slightly lower growth rate for the re-cultured fibroblasts at six months. In terms of cell morphology, keratinocytes appears to be cuboidal in shape (Figure 3) whilst fibroblasts appear to be elongated and spindle-shaped before and after cryopreservation (Figure 4). This indicates that both cells were able to maintain their morphologies even after twelve months of cryopreservation.

\section{IMMUNOCYTOCHEMISTRY ANALYSIS}

Immunocytochemistry analysis was performed to determine the expression of specific surface protein markers in the keratinocytes and fibroblasts. This helps to determine if there were variations in the expression of the protein markers before and after cryopreservation. Immunocytochemistry analysis showed positive expression of cytokeratin 14 (keratinocytes) (Figure 5) and collagen type I (fibroblasts) (Figure 6) even after twelve months of cryopreservation. This indicates the ability of the cells to retain their characteristics in terms of specific protein expression after cryopreservation.

Studies in the field of tissue engineering have brought a lot of promise in treating patients with various health conditions (Aminuddin \& Ruszymah 2008; Ruszymah 2008; Saim et al. 2004). The possibilities of regenerating living organs and tissues have helped researchers to embark on studies on different aspects of regenerative medicine. Therefore, in order to make this possible, the use of human-derived cells is of great importance as it will exert the best outcome on studies done in vitro. While many studies involved optimizing cell culture methods (Ibnubaidah et al. 2008; Yazid et al. 2008)
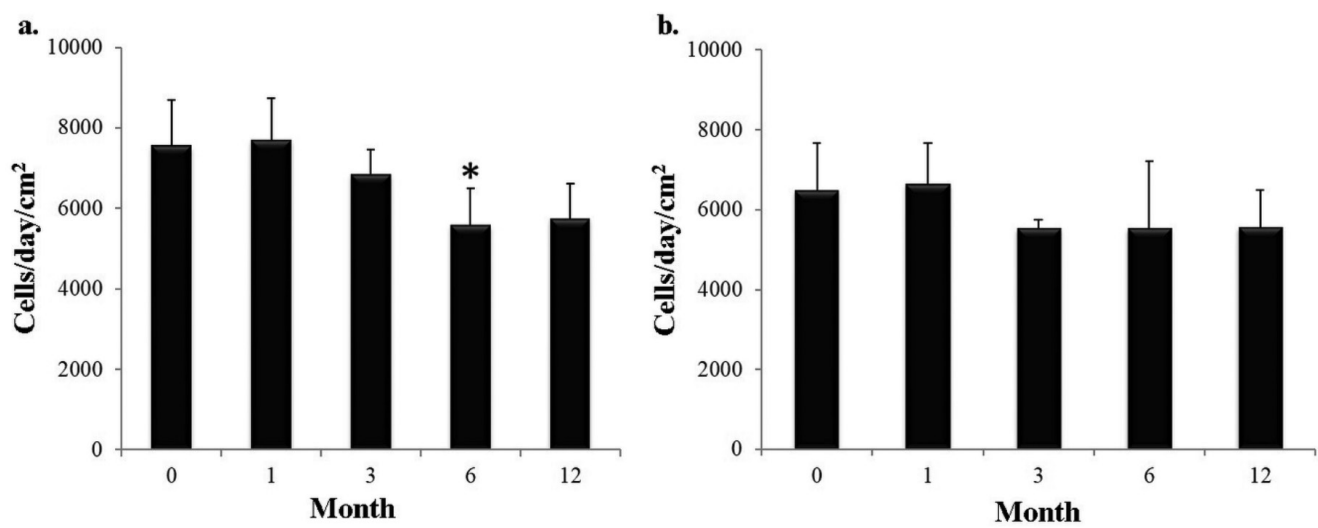

FIGURE 2. Growth rate analysis of a) fibroblasts and b) keratinocytes. Both cells maintained their growth rate performance after 12 months of cryopreservation. *represents significantly lower compared to 0 month. $p<0.05$

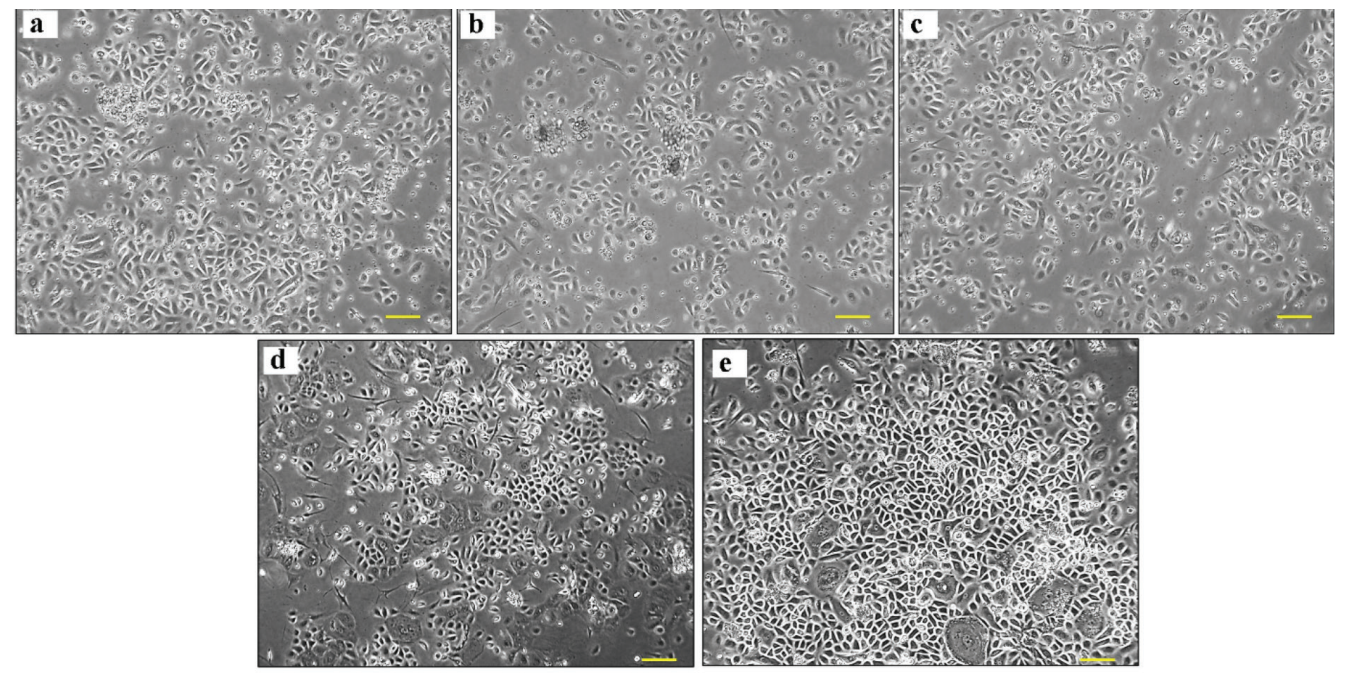

FIGURE 3. Phase contrast picture of keratinocytes. The cells morphology are cuboidal in shape and retain its morphology in a) control, and after b) 1 month, c) 3 months, d) 6 months, and e) 12 months of cryopreservation. Scale bar is $100 \mu \mathrm{m}$ 

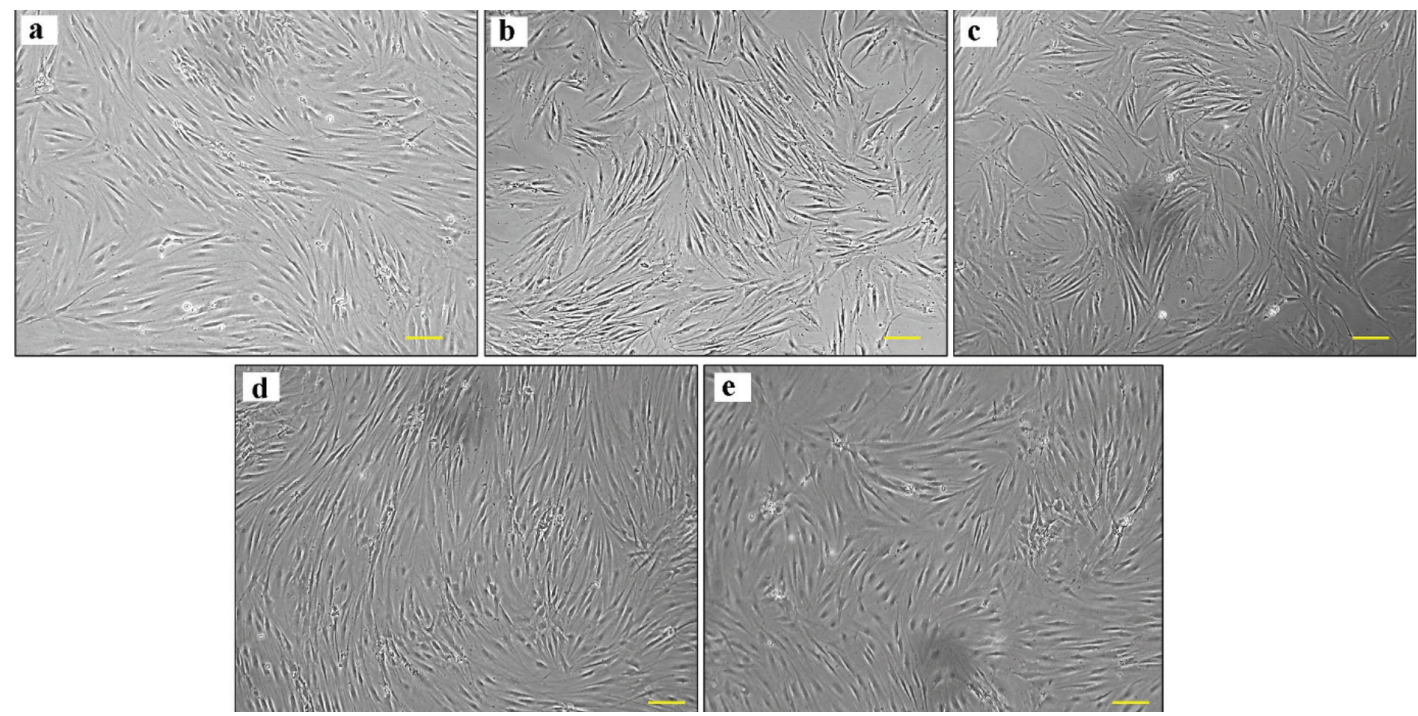

FIGURE 4. Phase contrast picture of fibroblasts. The cells morphology are elongated and spindledshape and retain its morphology in a) control, and after a) 1 month, b) 3 months, c) 6 months, and

d) 12 months of cryopreservation. Scale bar is $100 \mu \mathrm{m}$

and gene expression analysis (Ishak et al. 2011; Law et al. 2016), the evaluation of primary human cells after cryopreservation has been rarely reported. As the use of animal cells in research is beneficial (Alfaqeh et al. 2008), to bring better understanding and interpretation of human cell behaviour, and as the demand for cells in research and development increases, it is therefore necessary to develop cell and tissue banks and determine the optimum storage condition that is cost-effective (Naaldijk et al. 2016). Tissue engineering is an emerging field of science, and a number of research institutes, even biotechnology companies are now venturing into catering research and development in the field of regenerative medicine. Hence, a number of companies, mostly based in USA, are now undertaking commercialisation of different types of ready-to-use cells. Unfortunately, the prices of these cells are very high, due to the cost of export, customs clearance, and taxes. Thus, it seems appropriate to develop an in-house cell distribution facility that is reachable to the local research institutes in Malaysia. Developing an efficient cryopreservation protocol and its validation is the first step towards it.

Studies have shown that cells can be successfully cryopreserved by using DMSO as a cryoprotecting agent (Stolzing et al. 2012). Studies have been carried out to investigate the use of different concentrations of DMSO for cell freezing (Stolzing et al. 2012); and also of DMSO combinations with different cryoprotectants (Naaldijk et al. 2016). We have used the combination of feotal bovine serum with $10 \%$ DMSO as the cryopreservation agent in this particular study. The decrease in viability is expected. According to Hunt et al. (2003), even though the cooling rates of $1-2.5^{\circ} \mathrm{C} / \mathrm{min}$ are probably optimal for DMSO concentrations of 5-10\%, recovery of the cells post-cryopreservation can be improved if the osmotic damage that occurs through the introduction and removal of the cryoprotectant is tempered by the application of slow addition or elution protocols (Hunt et al. 2003). Nonetheless, Naaldijk et. al (2016) has also shown that the combination of DMSO and hydroxyethyl compound at a certain ratio might give a better cell yield postcryopreservation. This is interesting for the researchers to look into as the use of other reagents may affect the cell viability and performance during cryopreservation. During cell cryopreservation, cells experience sudden changes in temperature in a short period of time which may cause cold shock, osmotic injury and intracellular ice formation (Gao $\&$ Critser 2000). Even though the cell viability decreased after twelve months of cryopreservation, both keratinocytes and fibroblasts still show an acceptable viability of more than $60 \%$ (Figure 1). This is supported by Yanaga et al. (2017) which reported that the viability for cryopreserved cultured epithelial cells was approximately $60 \%$ after a year of cryopreservation (Yanaga et al. 2017). Another important issue to be considered is the technique and methods of freezing (Schiozer et al. 2013). Cells should be cooled gradually and thawed rapidly in order to achieve a good viable number of cells (Udoh et al. 2000), similar to what is done in the present study.

As the cells are being culture-expanded and cryopreserved, the evaluation of protein expression is important to detect any changes in its specific proteins. Immunocytochemistry analysis was performed to evaluate the expression of CK-14 in keratinocytes and collagen type-I in fibroblasts. After twelve months of cryopreservation, both markers were expressed by both cells, respectively. CK-14 is a basal-type cytokeratin and expressed in basal cells of multi-layered epithelia (Bocker 2002). Katayama et al. (2015) previously conducted a study on the differences in gene expression in keratinocytes from different sources. The results showed that cultured keratinocytes 

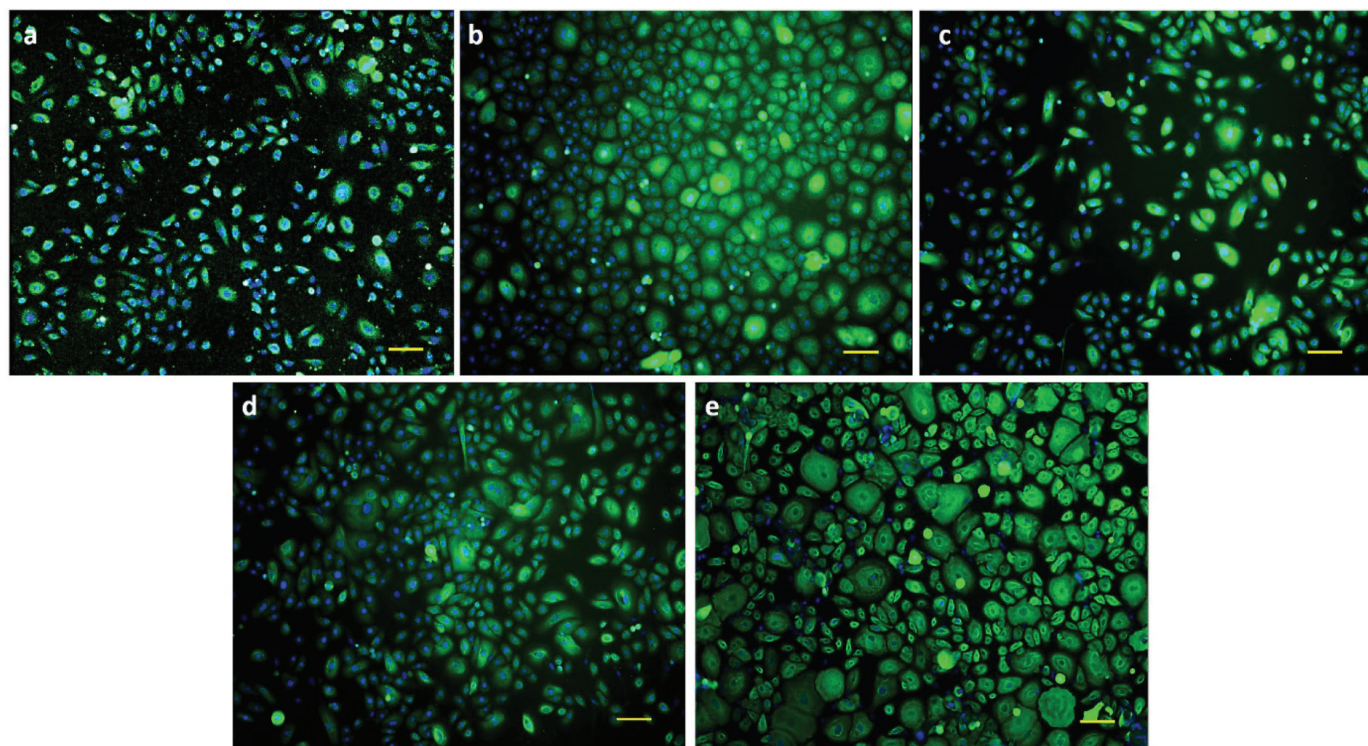

FIGURE 5. Immunocytochemical analysis of keratinocytes. The specific markers for keratinocytes

(Cytokeratin 14) were strongly expressed (marked with green colour) for a) control, and

after b) 1 month, c) 3 months, d) 6 months, and e) 12 months of cryopreservation. Scale bar is $100 \mu \mathrm{m}$
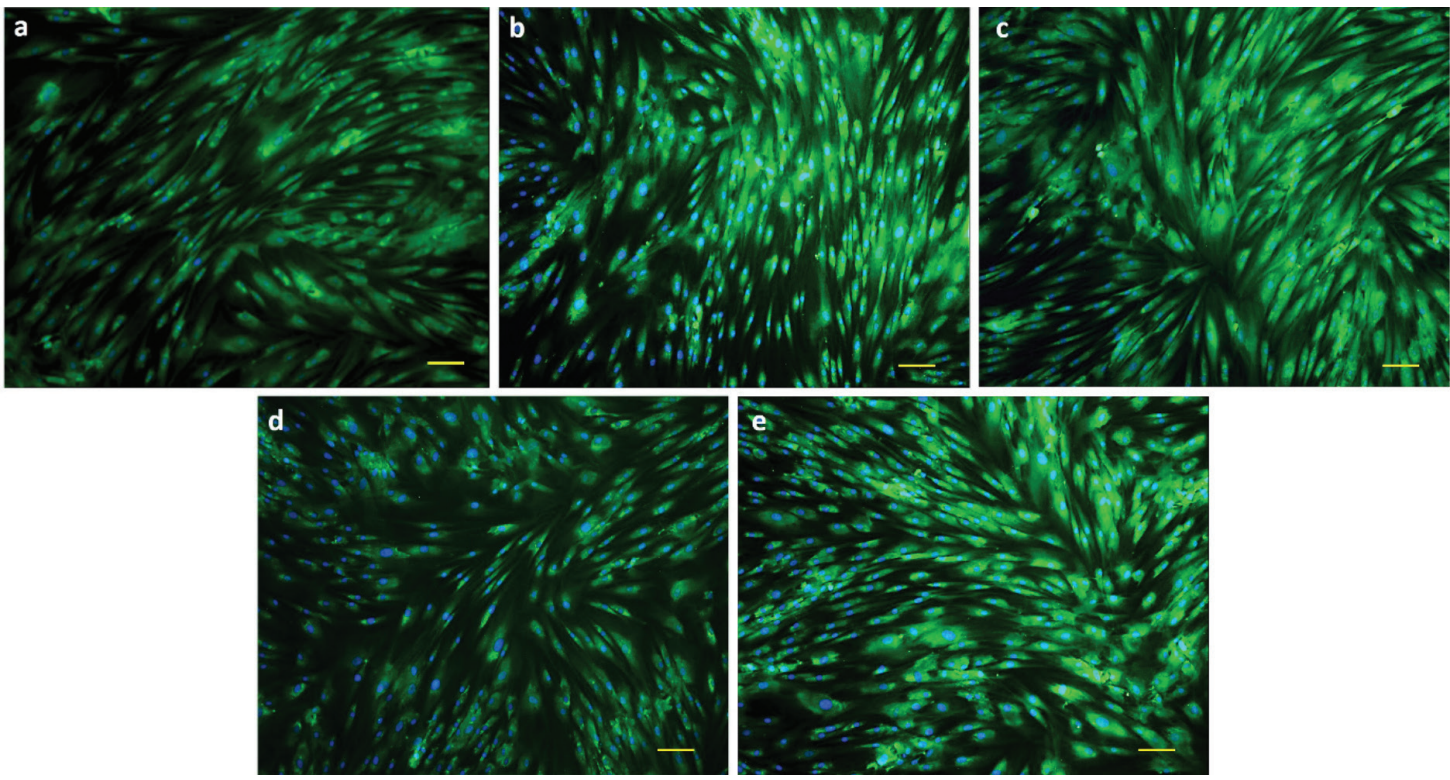

FIGURE 6. Immunocytochemical analysis of fibroblasts. The specific markers for fibroblast (Collagen type I) were strongly expressed (marked with green colour) for a) control, and after b) 1 month,c) 3 months, d) 6 months, and e) 12 months of cryopreservation. Scale bar is $100 \mu \mathrm{m}$

expressed a significant amount of CK-14 even after serial passaging which indicates cells were able to maintain their proliferative activity after serial passaging (Katayama et al. 2015). In addition, a study by Alam et al. (2011) indicates that CK-14 played an important role as a negative regulator of cell differentiation and may act as a possible control in terms of the squamous differentiation process (Alam et al. 2011). In contrast, collagen type I is known to be an integral structural component of the extracellular matrix in the dermal layer of skin mainly synthesised by fibroblasts (Chen et al. 1999). A study by Kim et al. (2014) showed that type I collagen in human skin acted as the main factor in skin aging and skin remodelling (Kim et al. 2014). Thus, the expression of the specific protein CK-14 and collagen type I after long-term cryopreservation showed that the keratinocytes and fibroblasts were able to maintain their important phenotype (Figures $5 \& 6$ ).

\section{CONCLUSION}

We have successfully assessed the characteristics of primary human skin cells after cryopreservation and 
showed that the cells are able to maintain expression of specific proteins. Even though the cell number and viability decreased with time, the cells remained within the range above $60 \%$ in terms of viability and a cell count of more than 500,000 cells/vial. However, further investigation using longer periods of cryopreservation (e.g 24 months, 48 months) should be conducted. The authors declare that they have no conflict of interest.

\section{ACKNOWLEDGEMENTS}

This study is funded by Cell Tissue Technology Sdn Bhd (Code Number: FF-2013-379).

\section{REFERENCES}

Adha, P.R., Chua, K.H., Mazlyzam, A.L., Low, K.C., Aminuddin, B.S. \& Ruszymah, B.H. 2008. Usage of allogeneic single layered tissue engineered skin enhance wound treatment in sheep. Med.J. Malaysia 63: 30-31.

Alam, H., Sehgal, L., Kundu, S.T., Dalal, S.N. \& Vaidya, M.M. 2011. Novel function of keratins 5 and 14 in proliferation and differentiation of stratified epithelial cells. Mol. Biol. Cell. 22(21): 4068-4078.

Alfaqeh, H., Norhamdan, M.Y., Chua, K.H., Chen, H.C., Aminuddin, B.S. \& Ruszymah, B.H. 2008. Cell based therapy for osteoarthritis in a sheep model: Gross and histological assessment. Med. J. Malaysia 63: 37-38.

Aminuddin, B.S. \& Ruszymah, B.H. 2008. Tissue engineering research in developing countries, the significant and differences as compared to the developed countries. Med.J. Malaysia 63: 47-48.

Bocker, W. 2002. WHO classification of breast tumors and tumors of the female genital organs: Pathology and genetics. Verh. Dtsch. Ges. Pathol. 86: 116-119.

Brockbank, K.G., Heacox, A.E. \& Schenke-Layland, K. 2011. Guidance for removal of fetal bovine serum from cryopreserved heart valve processing. Cells Tissues Organs 193(4): 264-273.

Chen, S.J., Yuan, W., Mori, Y., Levenson, A., Trojanowska, M. \& Varga, J. 1999. Stimulation of type I collagen transcription in human skin fibroblasts by TGF-beta: Involvement of Smad 3. J. Invest. Dermatol. 112(1): 49-57.

Chowdhury, S.R., Aminuddin, B.S. \& Ruszymah, B.H. 2012. Effect of supplementation of dermal fibroblasts conditioned medium on expansion of keratinocytes through enhancing attachment. Indian J. Exp. Biol. 50(5): 332-339.

Frey, N.V., Lazarus, H.M. \& Goldstein, S.C. 2006. Has allogeneic stem cell cryopreservation been given the 'cold shoulder'? An analysis of the pros and cons of using frozen versus fresh stem cell products in allogeneic stem cell transplantation. Bone Marrow Transplant 38(6): 399-405.

Gao, D. \& Critser, J.K. 2000. Mechanisms of cryoinjury in living cells. ILAR J. 41(4): 187-196.

Gurtovenko, A.A. \& Anwar, J. 2007. Modulating the structure and properties of cell membranes: The molecular mechanism of action of dimethyl sulfoxide. J. Phys. Chem. B 111(35): 10453-10460.

Hunt, C.J. 2011. Cryopreservation of human stem cells for clinical application: A review. Transfus. Med. Hemother. 38(2): 107-123.

Hunt, C.J., Pegg, D.E. \& Armitage, S.E. 2006. Optimising cryopreservation protocols for haematopoietic progenitor cells: A methodological approach for umbilical cord blood. Cryo Letters 27(2): 73-86.

Hunt, C.J., Armitage, S.E. \& Pegg, D.E. 2003. Cryopreservation of umbilical cord blood: 2. Tolerance of CD34(+) cells to multimolar dimethyl sulphoxide and the effect of cooling rate on recovery after freezing and thawing. Cryobiology 46(1): 76-87.

Ibnubaidah, M.A., Chua, K.H., Mazita, A., Azida, Z.N., Aminuddin, B.S., Ruszymah, B.H. \& Lokman, B.S. 2008. Derivation of cochlea hair cell for in vitro expansion and characterization. Med.J. Malaysia 63: 115-116.

Ishak, M.F., Chua, K.H., Asma, A., Saim, L., Aminuddin, B.S., Ruszymah, B.H. \& Goh, B.S. 2011. Stem cell genes are poorly expressed in chondrocytes from microtic cartilage. Int. J. Pediatr. Otorhinolaryngol. 75(6): 835-840.

Kalyanaraman, B. \& Boyce, S.T. 2009. Wound healing on athymic mice with engineered skin substitutes fabricated with keratinocytes harvested from an automated bioreactor. J. Surg. Res. 152(2): 296-302.

Katayama, S., Skoog, T., Jouhilahti, E.M., Siitonen, H.A., Nuutila, K., Tervaniemi, M.H., Vuola, J., Johnsson, A., Lonnerberg, P., Linnarsson, S., Elomaa, O., Kankuri, E. \& Kere, J. 2015. Gene expression analysis of skin grafts and cultured keratinocytes using synthetic RNA normalization reveals insights into differentiation and growth control. $B M C$ Genomics 16: 476.

Kim, M.S., Song, H.J., Lee, S.H. \& Lee, C.K. 2014. Comparative study of various growth factors and cytokines on type I collagen and hyaluronan production in human dermal fibroblasts. J. Cosmet. Dermatol. 13(1): 44-51.

Law, J.X., Musa, F., Ruszymah, B.H., El Haj, A.J. \& Yang, Y. 2016. A comparative study of skin cell activities in collagen and fibrin constructs. Med. Eng. Phys. 38(9): 854-861.

Liu, G., Zhou, H., Li, Y., Li, G., Cui, L., Liu, W. \& Cao, Y. 2008. Evaluation of the viability and osteogenic differentiation of cryopreserved human adipose-derived stem cells. Cryobiology 57(1): 18-24.

Manira, M., Khairul Anuar, K., Seet, W.T., Ahmad Irfan, A.W., Ng, M.H., Chua, K.H., Mohd Heikal, M.Y., Aminuddin, B.S. \& Ruszymah, B.H. 2014. Comparison of the effects between animal-derived trypsin and recombinant trypsin on human skin cells proliferation, gene and protein expression. Cell Tissue Bank 15(1): 41-49.

Mazlyzam, A.L., Aminuddin, B.S., Saim, L. \& Ruszymah, B.H. 2008a. Human serum is an advantageous supplement for human dermal fibroblast expansion: Clinical implications for tissue engineering of skin. Arch. Med. Res. 39(8): 743-752.

Mazlyzam, A.L., Aminuddin, B.S., Saim, L. \& Ruszymah, B.H. 2008b. Living bilayered human skin equivalent: Promising potentials for wound healing. Med. J. Malaysia 63: 32-33.

Mazlyzam, A.L., Aminuddin, B.S., Fuzina, N.H., Norhayati, M.M., Fauziah, O., Isa, M.R., Saim, L. \& Ruszymah, B.H. 2007. Reconstruction of living bilayer human skin equivalent utilizing human fibrin as a scaffold. Burns 33(3): 355-363.

Mazlyzam, A.L., Aminuddin, B.S., Lokman, B.S., Isa, M.R., Fuzina, H., Fauziah, O. \& Ruszymah, B.H. 2004. Quality evaluation analysis of bioengineered human skin. Med. J. Malaysia 59: 39-40.

Muhd Fakhruddin, B.H., Aminuddin, B.S., Mazlyzam, A.L. \& Ruszymah, B.H. 2004. The effects of age on monolayer culture of human keratinocytes for future use in skin engineering. Med.J. Malaysia 59: 182-183. 
Naaldijk, Y., Johnson, A.A., Friedrich-Stockigt, A. \& Stolzing, A. 2016. Cryopreservation of dermal fibroblasts and keratinocytes in hydroxyethyl starch-based cryoprotectants. BMC Biotechno. 16(1): 85.

Norhayati, M.M., Mazlyzam, A.L., Asmah, R., Fuzina, H., Aminuddin, B.S., Ruszymah, B.H. \& Fauziah, O. 2004. Collagen fibers an important entity in skin tissues remodeling. Med. J. Malaysia 59: 184-185.

Ortiz-Lopez, L., Gonzalez-Olvera, J.J., Vega-Rivera, N.M., Garcia-Anaya, M., Carapia-Hernandez, A.K., VelazquezEscobar, J.C. \& Ramirez-Rodriguez, G.B. 2017. Human neural stem/progenitor cells derived from the olfactory epithelium express the TrkB receptor and migrate in response to BDNF. Neuroscience 355: 84-100.

Pasch, J., Schiefer, A., Heschel,I. \& Rau, G. 1999. Cryopreservation of keratinocytes in a monolayer. Cryobiology 39(2): 158-168.

Rheinwald, J.G. \& Green, H. 1975. Formation of a keratinizing epithelium in culture by a cloned cell line derived from a teratoma. Cell 6(3): 317-330.

Roseeuw, D., De Coninck, A., Neven, A.M., Vandenberghe, Y., Kets, E., Verleye, G. \& Rogiers, V. 1991. Fresh and cryopreserved cultured keratinocyte allografts for wound healing. Toxicol. in Vitro 5(5-6): 579-583.

Rowley, S.D., Bensinger, W.I., Gooley, T.A. \& Buckner, C.D 1994. Effect of cell concentration on bone marrow and peripheral blood stem cell cryopreservation. Blood 83(9): 2731-2736.

Rubinstein, P., Dobrila, L., Rosenfield, R.E., Adamson, J.W., Migliaccio, G., Migliaccio, A.R., Taylor, P.E. \& Stevens, C.E. 1995. Processing and cryopreservation of placental/umbilical cord blood for unrelated bone marrow reconstitution. Proc. Natl. Acad. Sci. US A 92(22): 10119-10122.

Ruszymah, B.H. 2008. Tissue engineering provides the potential to replace and regenerate. Med. J. Malaysia 63: 27-28.

Ruszymah, B.H., Chua, K.H., Mazlyzam, A.L. \& Aminuddin, B.S. 2011. Formation of tissue engineered composite construct of cartilage and skin using high density polyethylene as inner scaffold in the shape of human helix. Int. J. Pediatr. Otorhinolaryngol. 75 (6): 805-810.

Saim, L., Aminuddin, B.S., Munirah, S., Chua, K.H., Izuddin Fahmy, A., Fuzina, N.H., Isa, M.R. \& Ruszymah, B.H. 2004. Formation of tissue-engineered human auricular cartilage via tissue engineering technique for future use in ear surgery. Med. J. Malaysia 59: 192-193.

Schiozer, W.A., Gemperli, R., Muhlbauer, W., Munhoz, A.M. \& Ferreira, M.C. 2013. An outcome analysis and long-term viability of cryopreserved cultured epidermal allografts: Assessment of the conservation of transplantable human skin allografts. Acta Cir. Bras. 28(12): 824-832.

Seet, W.T., Manira, M., Khairul Anuar, K., Chua, K.H., Ahmad Irfan, A.W., Ng, M.H., Aminuddin, B.S. \& Ruszymah, B.H. 2012. Shelf-life evaluation of bilayered human skin equivalent, MyDerm. PLoS One 7(8): e40978.

Stolzing, A., Naaldijk, Y., Fedorova, V. \& Sethe, S. 2012. Hydroxyethylstarch in cryopreservation - Mechanisms, benefits and problems. Transfus. Apher. Sci. 46(2): 137-147.

Teepe, R.G., Kreis, R.W., Koebrugge, E.J., Kempenaar, J.A., Vloemans, A.F., Hermans, R.P., Boxma, H., Dokter, J., Hermans, J. \& Ponec, M. 1990. The use of cultured autologous epidermis in the treatment of extensive burn wounds. J. Trauma 30(3): 269-275.
Udoh, Y., Yanaga, H., Tai, Y., Kiyokawa, K. \& Inoue, Y. 2000. Long-term viability of cryopreserved cultured epithelial grafts. Burns 26(6): 535-542.

Woods, E.J., Perry, B.C., Hockema, J.J., Larson, L., Zhou, D. \& Goebel, W.S. 2009. Optimized cryopreservation method for human dental pulp-derived stem cells and their tissues of origin for banking and clinical use. Cryobiology 59(2): 150-157.

Yanaga Hiroko, Yukihiro Udoh, Misa Yamamoto, Satoko Yoshii, Seiichiro Mori, Toshihiko Yamauchi, Kensuke Kiyokawa, Mika Koga \& Katsu Yanaga. 2017. Cryopreserved cultured epithelial allografts for pediatric deep partial dermal burns: Early wound closure and suppression of scarring. Regenerative Therapy 6: 74-82.

Yazid, A.G., Anuar, A., Onhmar, H.T., Ng, A.M., Ruszymah, B.H. \& Amaramalar, S.N. 2008. Sourcing different neuroprogenitor cell for the use of nerve construct. Med. J. Malaysia 63: 113-114.

Zhou, C.Q., Mai, Q.Y., Li, T. \& Zhuang, G.L. 2004 Cryopreservation of human embryonic stem cells by vitrification. Chin. Med.J.(Engl) 117(7): 1050-1055.

Ishak, M.F., Manira, M. \& Ng, M.H.

Tissue Engineering Centre

Universiti Kebangsaan Malaysia Medical Center

Jalan Yaacob Latif

56000 Kuala Lumpur, Federal Territory

Malaysia

Khairul, B. \& Gargy, L.

Cell Tissue Technology Sdn Bhd

Kuala Lumpur, Federal Territory

Malaysia

Aminuddin, B.S

Ampang Puteri Specialist Hospital

68000 Ampang, Selangor Darul Ehsan

Malaysia

Ruszymah, B.H.I.*

Departments of Physiology

Faculty of Medicine

Universiti Kebangsaan Malaysia Medical Centre

Jalan Yaacob Latif

56000 Kuala Lumpur, Federal Territory

Malaysia

*Corresponding author; email: ruszyidrus@gmail.com

Received: 30 March 2018

Accepted: 5 September 2018 